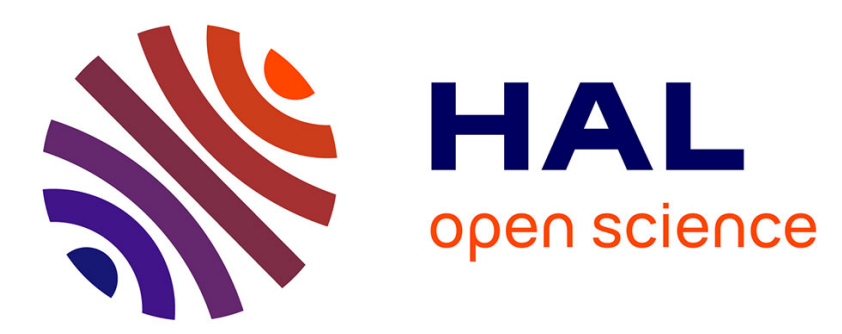

\title{
Adding value to randomization with qualitative analysis : the case of microcredit in rural Morocco
}

Solène Morvant-Roux, Isabelle Guérin, Marc Roesch, Jean-Yves Moisseron

\section{To cite this version:}

Solène Morvant-Roux, Isabelle Guérin, Marc Roesch, Jean-Yves Moisseron. Adding value to randomization with qualitative analysis : the case of microcredit in rural Morocco. World Development, 2014, 56, pp.302-312. 10.1016/j.worlddev.2013.03.00 . ird-01471911

\section{HAL Id: ird-01471911 \\ https://hal.ird.fr/ird-01471911}

Submitted on 20 Feb 2017

HAL is a multi-disciplinary open access archive for the deposit and dissemination of scientific research documents, whether they are published or not. The documents may come from teaching and research institutions in France or abroad, or from public or private research centers.
L'archive ouverte pluridisciplinaire HAL, est destinée au dépôt et à la diffusion de documents scientifiques de niveau recherche, publiés ou non, émanant des établissements d'enseignement et de recherche français ou étrangers, des laboratoires publics ou privés. 


\section{Adding value to randomization with qualitative analysis: the case of microcredit in rural Morocco}

Morvant-Roux S., Guérin I., Roesch M. Moisseron J.-Y (201) Adding value to randomization with qualitative analysis: the case of microcredit in rural Morocco, World Development, 56: 302-312

Version de février 2013

Morvant-Roux Solène, Department of political economy, Fribourg University, Switzerland Guérin Isabelle, UMR 201 Développement et Sociétés, Institute of Research for Development, Roesch Marc, CIRAD, Montpellier, France; French Institute of Pondicherry, Pondicherry, India Moisseron Jean-Yves, UMR 201 Développement et Sociétés, Institute of Research for Development.

\section{ABSTRACT}

This paper analyses microcredit demand and use to draw lessons how households appropriate microcredit services. It introduces qualitative analysis to a randomized study. Findings suggest that microcredit demand and use is shaped not only by agro-ecological conditions, but by two major pratially interrelated factors: debt-related norms articulated with the perception of the sanction in case of repayment default, and the "social life" of microcredit, namely, how social actors, credit officers and local leaders, engage with microcredit. On a conceptual perspective we argue that microcredit "markets" do not result from supply confronting demand, but instead, are historical, political and social constructs.

Key words: Microcredit take-up, defaults, methods, Northern Africa, Morocco

JEL Classification: O16; O17; O56; Z13 


\section{INTRODUCTION}

While it was long believed that all the poor were credit constrained and that cash shortages drove credit demand, there is now growing recognition that social, moral, cultural and political criteria also govern credit demand and usage (Lont and Hospes, 2004; Guérin Morvant-Roux \& Servet, 2011, 2012a; Johnson 2004; Shipton 2007). Despite these recent advances in understanding, setting up a microcredit service is still too often viewed as a technical, linear process, as reflected in guidelines that credit officers simply administrate services for clients, who are passive consumers. Microcredit is not however a monolithic project, and its initiatives are contextually specific, nuanced processes (Fernando, 2006), occurring within social, economic, political and cultural settings rife with opportunities and constraints. Local environments impact upon credit demand and how microcredit services are set up. This paper examines microcredit demand and use in rural Morocco as a case study of how households appropriate microcredit services. By this we mean not just how they use or reject such services, but how they assimilate them in reflection of their own frames of social and cultural references.

Rural Morocco is an interesting case study in terms of broad trends in the microfinance industry. There has been a massive, but patchy, growth in microcredit in Morocco since the mid-1990s. The country has long been considered as the flagship of Arabic microcredit, both in terms of outreach and for the "good governance" of Moroccan microcredit associations. But the industry has been facing a serious delinquency crisis since 2008, the year in which the Fondation Banque Populaire took over one of the biggest microfinance providers, Zakoura (including its losses). Al Amana, another of the country's biggest microcredit providers and the focus of our study, has also been facing a delinquency crisis since 2008. In the meantime, microcredit providers have been trying to expand their customer base into rural Morocco. Until the mid 2000s, there was a primarily urban market concentrated in Casablanca, Fez, and Marrakesh (Planet Finance, 2006). The biggest microcredit providers are now looking to redress this urban bias and the saturation of urban markets by targeting rural areas.

Al Amana began to diversify its portfolio in 2006, but rural diversification has proved a major challenge. A randomised impact assessment done by the Abdul Latif Jameel Poverty Action Lab (J-PAL) has shown that despite specific measures to enhance take-up rates, participation rates of the overall 
branches' sample were quite low while varying a lot between villages (between 0 and $80 \%$ ). Quantitative analysis fails to capture determinants of participation (Duflo et al. 2008). First, variability seems strongly related to unobserved heterogeneity (the share of the variance related to unobserved heterogeneity is $82 \%)$. Second, the model cannot explain considerable differences among villages. Moreover, pockets of default of up to $80 \%$ of borrowers from a village have been found in a number of rural areas. The findings of the J-PAL study were the starting point for our research. Their model had limited predictive capacities and could only marginally increase the rate of participants. The study's commissioners, the French Agency for Development, asked our team to qualitatively explain why microcredit demand in rural areas was low and heterogeneous. The aim was to capture previously unobserved characteristics at both individual and village/regional levels.

A first finding is that $\mathrm{Al}$ Amana microcredit is not tailored to specific agricultural and rural constraints, as is the case for the microcredit industry worldwide, which is unable to adapt to seasonal constraints, low profitability in agriculture and climate hazards (Morvant-Roux, 2009). Supply is in fact best tailored for consumption needs and regular income households in peri-urban villages. Beyond agro-ecological factors, our application of economic anthropology and ethnography of development project indicates that microcredit demand and use is influenced by two main inter-related factors: debt-related norms and the "social life" of microcredit.

Most of the literature on microfinance looks to assess the impact of microfinance on borrowers' wellbeing, or to deconstruct it as a new form of power and control over the poor (Fernando 2006, Rankin, 2002). These two approaches are undoubtedly useful and necessary. The lived experience of microcredit as debt, fundamental as it is from a policy perspective, remains a relatively neglected area, however. Economic anthropology has shown that economics and finance are both shaped by and constitutive of social relationships, moral values and culture. Economics and finance have no universal meanings, but a variety of meanings and formulations within particular cultures (Gudeman, 2001; Hann \& Hart, 2011; Shipton, 2007). In spite of these findings, only scant literature examines how norms, institutions and values influence demand for and the use of microcredit, all of which highlights the discrepancies between "foreign" and local categories. Terms often considered universal such as "loan", "repayment" 
or "interest rate", in fact take on a variety of local meanings, which can lead to intractable misunderstandings and the misuse of microcredit programs (Shipton, 2010; Guérin, Morvant-Roux \& Villarreal, 2013; Johnson, 2013). As meanings and norms are neither fixed nor pre-determined but the outcome of structural mechanisms and specific contingencies, they often vary across space (and time). This paper looks to address this neglected topic.

For social, cultural and moral reasons, debt can be considered a normal part of the human condition (Malamoud, 1980) or as something that should be avoided (Bourdieu, 1977). In rural Morocco, many rural households are reluctant to go into debt and this explains why participation to microcredit is low (on average). We find, within our sample of villages, that microcredit has multiple context-specific, contextually generated meanings. Structural factors such as the norms of debt, honor and dignity, the local history of credit planned interventions, and relations to authority and the state, are important. Our research finds that $\mathrm{Al}$ Amana is usually seen as coming from the Maghzen (central authority, king), such that there are fears of sanction generating a great reluctance to borrow in some villages. In other villages however, precisely because microcredit is perceived as coming from the state, it is considered as a nonrepayable debt, resulting in both massive participation and default. Equally key are the particular circumstances, social and political processes at play that influence the way in which a specific microcredit scheme is set up in a given area, what can be called the "social life" of microcredit. Individual credit officers and local leaders can significantly influence how microcredit is represented, envisioned and understood.

From a methodological perspective, our findings highlight the importance of qualitative analysis, not as a substitute but as a complement to quantitative analysis: borrowers' testimonies are the only way to detect how people build and negotiate multiple meanings and understandings of microcredit, which in turn shape the way they experience, use, misuse or reject microcredit services. In terms of policy, our findings shed light on the challenges financial inclusion policies face in rural areas.

Section 1 presents our theoretical framework, while Section 2 sets out the research context and methodology. Section 3 examines how cultural and religious norms of debt are linked to low demand for credit. Section 4 explores the different factors of heterogeneity of debt and repayment such as agro- 
ecological characteristics, perceptions of central authority and the 'social life' of microcredit. Section 5 gives our conclusions and the major implications of this research.

\section{THEORETICAL FRAMEWORK}

Several economic investigations have sought to unravel what determines financial service usage from different angles (Johnson, 2005). A first approach focuses on contractual characteristics of different credit providers, looking at economic efficiency, collateral, transaction costs and information. Following the seminal work by Stiglitz and Weiss (1981), major empirical contributions include Kochar (1997), Guirkinger (2008), Boucher et al. (2009). Going beyond the view of financial relationships as shortterm transactions between individuals making choices on the basis of limited criteria such as financial and opportunity costs, later approaches have analysed how social institutions influence the emergence and ongoing renewal of financial arrangements (Bouman, 1995; Bouman and Hospes, 1994; HarrissWhite and Colatei, 2004; Servet, 1995, 2006). They analyze financial arrangements in relation to evolving legal-institutional, social-economic and agro-ecological settings. Its major conclusion is that microcredit use is differentiated along various lines such as gender (Johnson, 2004; Guérin, 2011), social relationships (Guérin et al. 2012a, 2012c; Morvant-Roux, 2009), age and education (Johnson and NinoZarazua, 2011), localization and agro-ecological conditions (Johnson and Nino-Zarazua, 2011; Bouman and Hospes, 1994; Lont and Hospes, 2004) and political systems (Tsai, 2004).

Regardless of the angle adopted, previous investigations have not addressed how people perceive and experience debt. Economic anthropology, in highlighting the social and cultural meaning of debt, is a useful and necessary complement to the current literature. From economic anthropology we know that individuals often accumulate debt and credit and repay loans on the basis of their own informal hierarchies and frameworks of calculation (Bouman \& Hospes, 1994; Guérin, 2006, 2011b; MorvantRoux, 2006; Bloch \& Parry, 1989; Servet, 2006; Shipton, 2007; Zelizer, 1995; Villarreal, 2004). This transcends material or self-centred motivation to reflect issues of status, honour, power, and individual as well as group identity. Just as debt has specific meanings across societies, there are many different kinds of debt ties and significations within a given society. The same amount of debt with the same cost 
can have a variety of meanings and very diverse consequences, depending on the nature of the social relationship between the lender and the borrower (Guérin, Morvant-Roux \& Villarreal, 2013). Not all debts are supposed to be repaid, or delays in repayment are regularly anticipated. Some debts are viewed as a right, others as a due, privilege or punishment (Villarreal, 2009).

When it comes to "outside" debt, it all depends on how each party negotiates and "frames" debt. When "each party to the transaction is not operating within the same social and cultural context, Johnson says, there is therefore space for different understandings" (Johnson, 2013). In Kenya, Shipton (2010) highlights the discrepancy between microcredit principles and local understanding of various concepts such as obligation, morality and interest rates. He shows how this leads to the rejection of schemes and/or very poor repayment rates. Drawing on different areas of the world, Guérin, Morvant-Roux \& Villarreal (2013) highlight the existing diversity of interpretations of concepts commonly used in the microfinance industry such as "arrears", "cross-debt", "solidarity groups" or "over-indebtedness". Accounting definitions can lie far from the realities they seek to measure.

Financial terms are not just abstract words used by project officers and development planners in their office and imposed on local populations. The ethnography of development, which is regrettably underused in the field of microcredit, allows us to approach microcredit as part of a social fabric where pre-existing cultural repertoires are reworked through social interactions. Development project stakeholders, be they beneficiaries, fieldworkers, managers or local leaders, do not consume or passively implement development, but 'coproduce' it. Development projects should be understood as ongoing negotiation processes within which stakeholders engage, interact, cooperate; conflict and more often compromise, while attributing values and meanings according to their own frameworks, interests and constraints. Looking at the social fabric of development projects allows analysing diverging responses to "similar structural circumstances, even if the conditions appear to be homogeneous" (Long, 1992: 9), as is our objective here.

This article draws on the insights from the economic anthropology of debt that credit and debt are not only financial flows but have social meaning, and from the ethnography of development that development projects are neither imposed from above nor entirely driven by below but co-produced. It 
addresses the many ways microcredit is internalised and framed, and comes to signify quite different things in different places.

\section{CONTEXT AND METHODOLOGY}

(a) Microcredit in Morocco

In 2009, there were 12 active microcredit institutions in Morocco, which combined had a portfolio of around 4.86 billion MAD ( $\$ 580$ million US) and over 950,000 active loans ${ }^{\mathrm{i}}$. Four organisations dominated the sector: Al Amana, Zakoura, Fondation pour le Développement Local et le Partenariat (FONDEP), and Fondation Banque Populaire pour le Microcrédit (FBPMC). These four leaders shared $97 \%$ of the sector's loan portfolio by the end of 2009, and ranked among North Africa's biggest microcredit institutions. Al Amana had issued 45\% of all the active loans (Al Amana, 2010). When it first started up, this organisation mostly focused on urban and peri-urban areas, but in 2005 it decided to diversify its clientele to include rural areas, creating new branches. The expansion was swift: as early as 2007 , rural areas accounted for $49 \%$ of Al Amana's portfolio, which has since held stable $(47 \%$ in August 2010).

Al Amana offers solidarity group and individual loans. Solidarity group loans are set up for a 3 to 18 months period, and amounts loaned can vary from 1,000 and 30,000 MAD (120 à 3500 US\$). These are repayable in weekly, bimonthly or monthly instalments, and amount to $45 \%$ of the loans Al Amana issued in 2010. Al Amana issues individual loans to clients who have previously borrowed as part of a solidarity group. These credits target investment in existing economic activities or housing, and are issued for 6 months to 5 years (or up to 7 years for housing loans). Loan amounts vary from 1,000 to 50,000 MAD (120 US\$- 5800 US\$), and individual loans account for 55\% of all loans. Al Amana does not provide saving services due to legislative restrictions. We shall return later to Al Amana's origins, and its social and political dimensions.

(b) Methodology of the research 
As already discussed, our research uses the results of a randomised trial evaluation as its starting point. Two striking findings emerged from this study: a low average take-up rate and significant disparities across and within regions (Crépon et al., 2011 p. 10). Our research looked to better understand these findings. Our first step was to measure the participation variability. Table 1 below sets out participation diversity across regions by the end of 2009 (termed "branches" by Al Amana). Out of the regions covered by wave 2 in the J-PAL study (treatment groups) almost half (47\%) have a participation rate of below $10 \%$, while $16 \%$ have a participation rate of above $16 \%$ ii . Measuring take-up was quite challenging, but the survey data indicates that total participation was $11 \%$ on average and $13 \%$ among the 25 households per village with the largest propensity to borrow (Crépon et al., 2011). Actually, in order to obtain a larger treatment sample that would enable the detection of smaller effects J-Pal modified the sampling scheme after the first wave. Starting with a rapid census on all the households of treatment villages, the team selected those 25 households per village that had the highest probability of becoming borrowers of the newly installed microcredit scheme, based on a propensity score parameterized using the data collected in the feasibility study.

Table 1. Take-up rate variation across regions

\begin{tabular}{|l|c|}
\hline $\begin{array}{c}\text { Take-up rates (wave 2, } \\
\text { 37 branches, dec-09) }\end{array}$ & $\begin{array}{c}\text { \% of branches } \\
\text { (regions) }\end{array}$ \\
\hline 0 to $9 \%$ & $47 \%$ \\
\hline 10 to $19 \%$ & $19 \%$ \\
\hline 20 to $29 \%$ & $19 \%$ \\
\hline Over $30 \%$ & $16 \%$ \\
\hline
\end{tabular}

Source: Al Amana and J-Pal follow up of take-up rates

Diversity in participation rates was not only found at the branch level, but also between villages of the same branches. We cannot unfortunately give illustrations of this level of heterogeneity because there were too few villages per branch to measure the level of variability. As noted in Duflo et al. (2008) about "Observable characteristics determining participation": "There are also considerable differences among villages... Unfortunately we do not have enough villages here to try to disentangle the various possible 
effects." (ibid, p.23). We saw significant gaps for the branch "MG- My Abdellah Ben Driss" (see table 3 below) where the rate greatly varies from one village to the next (5\% to over $43 \%$ of the population). In the case of "LJ", the total take-up rate for the branch is $1 \%$, which made it too low to see any heterogeneity across villages.

(i) Data collection and sampling

Quantitative analysis - the collection and analysis of standardized data from large samples- is best suited to identify regularities and correlations. Qualitative analysis is critical to analyze issues that are difficult to summarize with numbers, as is clearly the case for norms, meanings and social interactions, which pertain to the immediate context in which people live. Qualitative analysis is best suited to disentangle and analyze cognitive and social processes that underlie observed effects, i.e. how a given intervention instigates events ultimately resulting in an observed outcome. Qualitative analysis is also useful for understanding heterogeneous situations, and itself draws on a wide range of methods. Ethnography looks to observe and interact with local populations in their daily lives without preconceived hypotheses. It is probably the best means to identify local categories and the complexity of social relationships in a specific context, but it requires a long-term presence in the same setting (village). Since our objective was to study the diversity of participation in microcredit schemes, we conducted individual and village level case studies using semi-structured interviews and observation. This less in-depth approach than classical ethnographic analysis nonetheless respects the basic principle of contextualization, allowing for comparison by drawing on a wide spectrum of local contexts and individual experiences. Five researchers with complementary specialisations (one in agro-economics, three in the socio-economics of finance and microfinance, and one in the political economics of Islamic societies) conducted 79 interviews in 17 villages, in varying spaces such as the home, workplaces and the office of Al Amana.

Information gathered from each branch allowed us to conduct interviews with clients (36) and nonclients (23) for two main purposes. The first was to contextualise the dynamics of debt and establish the chronology of households' experiences. We wanted to ascertain the main financial strategies being used and whether households mainly take on debt to pay for major life events and/or crises. Interviewees 
were asked to list their major life events (life cycle events, livelihood changes, migration, etc.) and their main sources of vulnerability. They were asked to explain how they had financed each event or noticeable change (the words microcredit and debt were never used by the interviewers to avoid influencing the answers, or to be associated with Al Amana).

Another purpose for the survey was to analyze attitudes and strategies toward debts, taking into account the diversity of debt relationships, both from a financial perspective (cost, repayment modalities, duration, etc.) and from a subjective perspective. Wherever possible, discourses regarding debt were confronted with practices - and it is here that the reconstruction of the main stages of the life cycle is a useful tool. Following Douglas (1980), quoted by Mosse (2005), the idea was to locate "the meanings of the words and concepts (...) in social activity" (Mosse, 2005: 10). Individual case studies were interpreted in the light of local contexts, at least to a certain extent. For example, while we observed the virtual disappearance of segmentary tribal societies, we could not examine the role they probably still play in local social and political arenas, and hence in the social life of microcredit.

Contextualizing data collection is also key. Clients may use a different discourse if at home rather than in the microfinance organisation's office, as may credit officers if they are in a teashop rather than their office. Triangulation of information was also central to our data collection process. Confronting observations from different researchers is a first method. Triangulation was also done through interviews from various categories of actors. We then interviewed five credit officers, as we believe they are key in shaping relationships with clients. We asked them to talk about their work, daily activities, experience and motivations, and main challenges with clients and their local environment, which served to highlight the key influence of local leaders. We also interviewed six imams, whom we assumed had some influence on local perceptions of the microcredit scheme through their religious discourse. We finally interviewed nine shopkeepers, whom we quickly realized were the main local informal lenders. We considered these three categories of actors as key sources of information and sought their testimonies as to their own roles and their opinions on local practices. Table 2 provides details of the main categories of actors interviewed. 
Table 2. Interviews detailed sample

\begin{tabular}{|l|c|}
\hline Clients & $\mathbf{3 6}$ \\
\hline Non-clients & 23 \\
\hline Imams & 6 \\
\hline Shop keepers & 9 \\
\hline Credit officers & 5 \\
\hline Total & 79 \\
\hline
\end{tabular}

(ii) Sample

In qualitative analysis size and representativeness are of minimal importance: diversity of situations and data saturation - i.e. when additional data collection provides no new information - are much more key. Our team selected four study areas from the 37 branches of Wave 2 sample (see footnote ${ }^{\circ} 2$ ). We chose branches with a steadily increasing client rate, but which were also experiencing disparities in client rates between villages (douars), and on the request of $\mathrm{Al} \mathrm{Amana,} \mathrm{we} \mathrm{also} \mathrm{included} \mathrm{a} \mathrm{branch}$ experiencing a high delinquency rate. Table 3 shows the branches included in the study and their takeup rates by December $2009^{\mathrm{iii}}$. As can be seen, take up rates ranges from 1\% (LJ Brachoua) and 6\% (CV Tighdouine) to 20.8\% (MG My Abdellah Ben Driss) and 19.6\% (AW Moulay Yacoub). For each branch, our aim was to conduct interviews in villages where participation rate profiles differed.

Table 3 Branches included in the sample and take-up rates

\begin{tabular}{|l|c|c|}
\hline Branch Name & $\begin{array}{l}\text { Take-up rate } \\
\text { (dec. 2009) }\end{array}$ & $\begin{array}{l}\text { Min-Max take-up rates for treatment } \\
\text { villages of the branch (dec. 2009) }\end{array}$ \\
\hline CV Tighdouine & $6 \%$ & $0-7 \%$ \\
\hline MG My Abdellah Ben Driss & $20.8 \%$ & $5 \%-43 \%$ \\
\hline AW Moulay Yacoub & $19.6 \%$ & Only one observation reported \\
\hline LJ Brachoua & $1 \%$ & Only one observation reported \\
\hline
\end{tabular}

Source: Al Amana and J-Pal follow up of take-up rates

(iii) Articulation with quantitative analysis

We drew on the J-PAL impact assessment study at different stages of our research in order to best complement it. In our sampling we used the follow up of microcredit take-up rates to select branches 
and villages. Interestingly, once our study was completed, a Master student from Paris School of Economics was able to access the baseline dataset (Silva-Gonçalves, 2011). She used our preliminary findings to examine the factors behind credit market participation. Her empirical strategy includes the Heckman selection model to assess demand and access to financial services and a multinomial logit model to assess participation in formal and informal credit markets. As we will see in what follows, her results strongly reinforce ours, while failing to explain certain factors which only qualitative analysis can reveal. The following two sections address our two initial questions as to why participation rates are both low and disparate.

\section{A LOW PROPENSITY TO GO INTO DEBT}

Various recent studies show that the analysis of informal finance can help to understand how people perceive microcredit (Collins et al. 2009; Guérin et al., 2011, 2012a). In comparison to other rural contexts $^{\text {iv }}$, the informal credit offer in rural Morocco is rather low. According to J-PAL's data (Crépon et al., 2011, p. 8), before $\mathrm{Al}$ Amana reached the treatment villages there was little use of formal and informal credit. Only $26 \%$ of households had some form of active loan and just $6 \%$ households used informal credit (grocers, neighbours, friends, etc.). These rates are much lower than what has been observed elsewhere. Qualitative field work in Bangladesh, southern India and South Africa by Collins et al. (2009) shows almost all their sampled households to be active borrowers who patch multiple sources of borrowing together (from 3 to 7 loans per households on average depending on the context) (ibid p. 50). A recent survey of 400 households in three rural settings also pointed to active participation in rural credit markets. In rural southern India households are all indebted, to an average of 4.8 predominantly informal sources (Guérin et al. 2012b). In rural Mexico, half of households are indebted to at least one formal credit provider, and all are indebted to informal providers such as shopkeepers (Morvant-Roux, Bouquet \& Rodriguez Solis, 2012). In rural Madagascar, 48 per cent of households are indebted (Zombre, 2013). Coming back to our Moroccan case, one might conclude, as did the J-PAL team, that household's indebtedness is low because households are highly credit constrained and that there is a strong potential for the development of microcredit (Crépon et al., 2011). But borrowers' 
testimonies in fact reveal that the demand is weak, simply because households are reluctant to borrow. We suggest that this reluctance is embedded within local cultural and religious norms.

Religion is often overlooked in development studies, although it clearly plays an important role (Deneulin \& Rakodi, 2011; Mersland et al. forthcoming). In Morocco, most people declare themselves as believer and practising Muslim. Therefore in theory, Islamic norm (sharia) prevail. The sharia is very clear as to the reprehensible and even illegal character (haram) of riba, i.e. interest. Far beyond interest rates however, being in debt is frowned upon. Only those who have paid their debts are allowed to go on pilgrimage to Mecca, one of the five pillars of Islam. This reluctance to take on debt is a matter of identity and social status: beyond religious issues - with which local people seem to have a rather pragmatic relationship - not being in debt is a matter of honor. Villagers testify that interest rates do not particularly put them off debt. They, as well as imams are well aware of riba, but take a highly pragmatic attitude to it. Al Amana moreover covers interest rates as an administrative fee. Debt, however, is often seen as a disgrace and a loss of dignity. In Algeria in the 1950s Pierre Bourdieu observed households' resistance to debt and argued that indebtedness implied that the head of a household had failed to meet his family's material needs (Bourdieu, 1977). Similar norms seem to continue in contemporary rural Morocco. "My pride will not let me go into debt" (Bricklayer/mason, Aitboujraf Douar, client). "If you were a man, you would not take out a loan", stated an elderly person whose son is an Al Amana client. "I want to be in charge of my life" (Farmer, Sidi Bengalssen, non-client), is how a non-client justifies his position. ${ }^{\vee}$ Discourses are not always confirmed by practice, and we encountered men and women who were very negative about debt yet regularly borrowed money. Nonetheless, negative comments were extremely widespread and highlighted the negative moral connotations of debt.

The multivariate analysis of J-Pal data inspired by our findings supports them (Silva-Gonçalves, 2011). It was found that four factors significantly influence probability of participation in credit markets. Household conservatism, measured by household heads' views on the rights or freedoms to be accorded to women, significantly lowers the probability of a household requesting any kind of credit. We can assume that households conservative in matters of gender are also more likely to subscribe to local norms. Education is positively correlated with demand for credit, and we can assume that educated 
households are more likely to question local norms. Household distance from souks and regional diversity are final factors to which we will return later.

The examination of informal financial practices is also instructive. The most common informal borrowing sources are shopkeepers and family members, who respectively amount to half and $36 \%$ of all lending sources according to J-Pal descriptive statistics. For both credit sources, there are no explicit interest rate and conditions are extremely flexible. All shopkeepers we met sell on credit, and play a central role in smoothing out households' daily cash flows. They are often native to their village and know the amount and frequency of families' sources income. They draw on this knowledge when lending, and thus have little need to exert repayment pressure. Amounts loaned are limited - on average 350 MAD (45 US\$), possibly up to 1000 MAD (136 US\$) for the wealthiest households - and repayment schedules are tailored to clients' liquidity constraints: weekly or bi-weekly for daily laborers, monthly for state employees or bi-monthly or quarterly for households who rely on migrants. Moreover, it is often women who borrow (when shopkeepers are located in the village), as they are in charge of family daily consumption, while men are responsible for repayment. This gendered aspect serves to preserve men's sense of honor. Relatives loan higher amounts - we encountered frequent cases of amounts ranging from $4000 \mathrm{MAD}$ to $15000 \mathrm{MAD}$ (450 US\$ to $1800 \mathrm{US \$ ).} \mathrm{These} \mathrm{are} \mathrm{used} \mathrm{to} \mathrm{finance} \mathrm{social} \mathrm{and}$ religious rituals, health expenses, and sometimes business activities. Repayments are also very flexible and depend on debtors' capacities and creditors' needs.

Finally, savings in kind are used to balance budgets. As in other contexts, goods of social and symbolic value such as cereals and livestock are used as savings. Both can be used to cover the costs of unpredictable eventualities such as health problems, religious festival and life cycle event costs, and to manage business cash flows. Beyond their savings function, these goods are used for personal consumption, but also financial and social accumulation. They therefore have a clear comparative advantage over microcredit for those who own it (around 50\% of households own cattle according to JPal data). Many of the villagers we interviewed felt no need for microcredit when they had cattle, or used microcredit to replenish their herds - a practice also observed by the J-Pal team (Crépon et al., 
2010, p.19-20). Low microcredit demand is therefore linked to a preference for saving. The following section explores the disparity of demand for microcredit between and within regions.

\section{DIVERSITY OF PATTERNS}

Our study highlights three factors for variations in borrowing: eco-type systems, perceptions of sanctions for defaulting, which are strongly related to perceptions of authority and the state, and finally, the role of credit officers and local leaders.

(a) Agro-ecological and economic diversity

Agro-ecological and economic diversity provided a first explanatory factor for the diversity in take-up rate. Using the criteria of agro-ecological landscape, livelihood opportunities and remoteness, we established three broad categories of area: mountain areas, peri-urban areas, and extensive farming areas. These differences have a considerable impact on credit demand and access to Al Amana microcredit services.

Type 1 areas are mountainous regions with small agricultural plots, where survival-type agricultural activity prevails and there are high levels of male migration to the cities for work. Local markets are extremely limited, incomes are low and irregular, and there is almost no potential for non-farming labour locally. From an economic perspective, households have neither the means nor the desire to borrow, as their needs are limited. In our sample, the take up in the mountain area is 6 per cent (see table 4).

Type 2 "peri-urban" areas are where the village is close enough to a city, town, or industrial or artisanal area, to allow for daily commuting to and from the city for work. Such proximity to centres of activity (towns, or industrial or agro-industrial areas) allows for a regular wage income. In this type of area, microcredit demand is, on average, higher, both because households have higher and more regular earnings and because they have greater needs (daily consumption, housing, and for some, business investment). In our sample, the take up reaches 20.8 per cent in the peri-urban area, and 19.6 per cent in the area combining peri-urban and extensive farming (see table 4). 
Type 3 zones cover fertile land, the relative flatness of which is better suited to mechanized farming operations. Larger farms exist side by side with small, unsustainable farms. Households in these areas do need credit, but most require large amounts for agricultural use. Al Amana's offer poorly matches their needs as its loan offers are too low, and regular instalments are demanded in the repayment schedule. As a result, participation rates in these areas are rather low on average. In our sample, the take up is 1 per cent in the extensive farming area. The relatively high participation in the mixed area (periurban/extensive farming) has to do with political reasons, as we will see later. Each branch in our study can be broadly situated within one of these categories of area as presented in table 4 . We will comment disparities in repayment in the last section.

Table 4 Typology of visited branches according to eco-type systems

\begin{tabular}{|l|l|l|l|}
\hline Branch & Eco type system & $\begin{array}{l}\text { Take-up (dec. } \\
\text { 2009) }\end{array}$ & $\begin{array}{l}\text { Portfolio at risk (30 } \\
\text { days) 2010 }\end{array}$ \\
\hline CV Tighdouine & Type 1 : Mountain area & $6 \%$ & $0.18 \%$ \\
\hline MG My Abdellah & Type 2 : Peri-urban area & $20.8 \%$ & $0.85 \%$ \\
\hline AW Mriss & & & \\
Yacoub & Type 2 et 3 : Peri-urban and & $19.6 \%$ & $37.4 \%$ \\
\hline LJ Brachoua & Type 3 : Extensive farming area & $1 \%$ & $22 \%$ \\
\hline
\end{tabular}

Source: Al Amana and J-Pal follow up of take-up rates and and Al Amana's reporting of repayment defaults

These agro-ecological differences greatly help to explain take-up heterogeneity across branches (in line with Bouman (1994)). As discussed above, Silva-Gonçalves' multivariate analysis (2011) applied our results to introduce a variable that captures regional characteristics. It turns out that the regional factor is one of the few significant explanatory variables of credit demand: areas with above average levels of agricultural land, infrastructure density and non-farming activities show higher demand for credit. This model does not however highlight barely quantifiable factors such as the perception of sanctions and 
local social interactions, particularly with local leaders and credit officers. We will now further deepen our analysis to show how such social, cultural and political factors influence demand for microcredit, and the ways it is used and appropriated.

(b) The perception of sanctions for defaulting

Several economic investigations have rightly pointed out how the risk of sanctions for defaulting can influence demand for credit. Drawing on empirical data from Peru, Guirkinger (2008), for instance, shows that anticipation of a sanction for repayment default reduces demand for formal credit: a deterrent to formal loans is that there are far more severe sanctions for repayment defaults than for informal loans. A central issue, raised by economic anthropology, is that of the subjective perception of sanctions. Going beyond the theoretical conditions of a credit contract, subjective perceptions of sanctions depend on a number of factors, including local credit supply history, and the degree of trust and proximity between suppliers and potential borrowers (Servet, 1996; Shipton, 2007).

In our study, the local perceptions of sanctions looked to be shaped by two factors. The first is how $\mathrm{Al}$ Amana is perceived as an organisation. Sometimes it is seen for what it is - a private Moroccan institution -, at others as a foreign institution, but mostly it is perceived as a government program. The discourse of some loan officers, which is discussed in more detail below, and Al Amana's history may account for these perceptions. In contrast to most Moroccan microcredit institutions, which were developed by civil society in opposition to Hassan II, the king at the time, the government strongly supported $\mathrm{Al}$ Amana at the outset, including offering funding sources (Lamrini, 2008: 39). While Al Amana is most often viewed as part of the state, attitudes towards sanctions for default depend on how local people perceive the central Moroccan state authority, known as the Maghzen, and this is the second factor. The idea of the Maghzen is essential for understanding Moroccan social structures and how people perceive their environment and outside interventions, whatever form they take (Cherifi, 1988). The Maghzen as a modern centralized state historically used violence to establish its power in different parts of the country. This led to a very negative perception of the Maghzen as symbolic of all the negative aspects of a central and authoritarian government, not least arbitrary violence, corruption and despotic 
authority, which tend either to be feared or accorded no legitimacy (Cherifi 1988). Moreover, while the Moroccan nation claims to have a dual Arabic and Berber identity, Berber communities generally do not identify with the central state.

These two perceptions combined - of Al Amana and its proximity to Maghzen, and the Maghzen itself - partially influence local perceptions of sanctions for repayment defaults. A continuum runs from intense fear (which contributes to low financial demand and self-exclusion), to strong feelings of impunity (which particularly impacts repayment rates, but also contributes to high demand). In the villages where this dimension proved instrumental, three scenarios schematically emerged. They depend heavily on the social positioning of microcredit clients (or non clients), the local environment but also the discourse of loan officers.

In the first scenario, households associate Al Amana with the Maghzen, which they fear. This false amalgamation was made time and again during interviews, with expressions such like "The money from AA is selef from Maghzen" (Selef from the Maghzen, here, means an advance, a loan from the Maghzen), or "It is Maghzen money","AA, it's like the Maghzen, a public establishment”. Amalgamating Al Amana's work with Maghzen money not only means there is more perceived pressure to repay, due to the gravity of any failure do so, but also discourages borrowing. The Maghzen is no abstraction: villagers associate it to the Maghzen's local representatives (caid) and allies (local notables). A small-hold farmer, once borrowed money to cover his daily expenses, but stopped. He stated that monthly repayments were difficult and if he didn't pay, "Al Amana will talk to the caid and I'll go to jail" (Farmer, Douar Ait Abbas, client). The spouse of a farmer who also migrates had heard of Al Amana but never borrowed money, being afraid of failing to manage repayments. “AA, it's Maghzen money, she says, if you don't pay, they'll come knocking with sticks" (farmer, Douar Boulajrouf, non-client).

The spouse of a mason, in payment arrears told us: "Sooner or later, I will pay because it is Maghzen money". She initially refused to talk to us and we felt that she was very nervous during the interview. She mentioned the local shopkeeper, an apparent local notable, to whom she probably owes money. She was afraid that the grocer would denounce her to the Maghzen, of which she asked: "it is the prison/ jail ?" (Spouse of a mason, Mchaa krim Douar, client). Fear of the Maghzen adds to the uncertainty these 
families already face. Most of them derive an irregular and unpredictable income from subsistence farming and remittances. During our time in branch offices, we heard some credit officers trying to persuade borrowers to repay by saying the money came from the Maghzen. This can partially account for the confusion of borrowers and potential borrowers. In another branch, a salaried seamstress, told us that the credit officer used similar threats to defaulters: "he tells us 'if you don't pay we will send you to Maghzen" (Salaried seamstress working from home, douar Mchaa krim, client).

A second scenario is that households still associate $\mathrm{Al}$ Amana with Maghzen, but view it as illegitimate. This promotes both participation and non-repayment. We saw this at the border of the Rif region, which is known for its alienation from the central authority (Guillen, 1970). Unlike the Berber from the remote regions of the South, historically people from the Rif have been able to develop forms of resistance through cannabis production and migration. In these areas, households' testimonies highlight great distrust in the state for wide-scale corruption and favouritism, which is used to justify their prevailing feelings of impunity. The following testimonies are from rather wealthy farmers who own several acres of land and often top up their earnings through migration. A Farmer was clear that failing to repay a debt to Al Amana was not stealing and posed no moral problems: "It is Maghzen money, but they are thieves, so we take it and we steal from the thieves" (Farmer, Tamrat douar, client). Another farmer, explained that people fail to pay because "it is money from nowhere", alluding to the outside nature of Al Amana (Farmer, Tamrat douar, non-client). A last interviewee, farmer, went further still, claiming: “it is thieves' money", when explaining clients' sense of impunity in deciding to borrow without repaying. In the following testimony, the borrower clarifies that debts are hierarchical: some should be repaid, others not.

"All local authorities are corrupt, demanding bribes for acts of civil status or to solve water problems. For the elections of farmers' representatives, there was violence and a mafia has filtered the voting. The population is not really afraid of the authorities. They are stigmatized and do not have much legitimacy. Non-repayment of the authorities is not a problem. But if you borrow from your family you should repay (Farmer, Tamrat douar, client). 
Local history of credit policies can also contribute to this feeling of impunity. For instance in the area of extensive agriculture of Brachoua, the loan officer refers to "red" areas known for non-payment for any form of public program. He cites the solar energy program, which the vast majority of families joined, but always refused to pay for. "Families living here have always refused to pay 65 MAD (6 US\$) per month, why would they be willing to pay back a microcredit?" he said. He also points out the negative impact of Credit Agricole's lax repayment policies, which set a "bad example". A farmer, we met said he had neighbors who borrowed from Al Amana without needing the money: "They play with money". This comment highlights that farmers don't take this type of loan particularly seriously. In this same douar, the public authorities are seen in a poor light and instantly associated with corruption. "Moqqadem, Caid, ....they are only interested in fluz (money). You give them money and you get what you want" (Farmer-breeder, Sidi Bengalssen douar, client). Not repaying is a way to get compensation for the abusive practices of the State. This attitude is accompanied by bitter criticism towards corruption. Outcomes thus vary a lot depending on relationship to the state. The Maghzen may be feared, but also challenged.

In the third scenario, Al Amana is considered as a "gift". In spite of Al Amana's multiple attempts to explain that this is not the case (for example, the branch's walls are plastered with posters stating that microcredits are not gifts and have to be repaid under all circumstances), there is frequent confusion, which boosts microcredit demand. This perception is sometimes maintained or passed on by local leaders, as we will see below. Some clients probably uphold the confusion on purpose to justify their own delays. The very fact that Al Amana holds a not-for-profit charitable status may also cause confusion, in particular in an Islamic context within which gifts are considered a pious obligation. People tend to consider that aid and development should be gifts. Some clients said that Al Amana used French or US aid. Rumours elsewhere stated that it is European or Japanese aid. This perception encourages participation but also defaults: as we were often told, "why repay when it is aid money?". This does not necessarily mean that people lack a sense of honour or morality, but that they prioritize their debts according to their own logic. 
(c) Credit officers and local leaders

Although social norms and institutions significantly influence microcredit programme participation, varying up-take responses also stem from specific interactions between those in charge of administrating the offer (credit officers) and local actors, whether clients or non-clients.

(i) Credit officers

Recent evidence has shed light on the nature and complexity of the relationship between credit agents and their clients, and the central role they play in building trust with their clients ${ }^{\mathrm{vi}}$. Their position is ambiguous because they are supposed to defend the interests of their institution, of their clients (with whom they need to build trusting relationships), as well as their own interests. Furthermore, because of increased financial profitability constraints, credit officers are pressurised by ever-higher portfolio objectives, and sometimes have trouble fulfilling their community role. In our case study, credit officers are highly influential as regards local population involvement with Al Amana. This influence, whether positive or negative, depends on their capacity to build close relationships with clients. How can we explain credit agents' variable capacities to foster trust and proximity? Two factors appear to be decisive: integration within the local social context, and village remoteness.

The first factor depends on whether officers originate from the area. The regional integration of their own family or in-laws, their networks beyond their place of birth, and their personal interests in their home region can all be presumed to come into play ${ }^{\text {vii }}$. Integration is key to agents' ability to understand local issues (whether economic activity or income-related), to assess the reliability of clients' discourses, to identity and assess potential clients in terms of their discourse and "morality" in order to avoid individuals with a bad reputation, to spot moral authorities liable to play a incentive role, and to know how to persuade people to take out loans (to go into debt) or to incite clients to repay in the event of a payment delay. There is evidence that the question of local knowledge has had an impact in the area to the north of AW branch, where the credit agent's outsider status helps contribute to the feeling of impunity previously described by this farmer:

“Some don't pay back because they are young. They took out a 5,000 MAD loan (575 US\$).

They bought wine and went to work in Ktama 100 kilometers away [in a cannabis production 
area]. They drank everything. They were not serious people. The people from Al Amana are not from this douar [village]. They don't know the people they lend to" (Farmer, Tamrat douar, client).

Credit officers' social integration is all the more important as they have little time to visit villages, in particular remote ones. The "passive" discrimination ${ }^{\text {viii }}$ undoubtedly comes into play here (Aubert et al., 2009; Labie et al., 2010). Certain villages are only accessible by donkey-back or by $4 x 4$, while others have been inaccessible for several months over the last two years because of severe flooding. Many meetings between agents and clients take place on the day of the Souk (market day), which allows to partially sidestep the problem, but home visits (which are part of the official procedure at the onset of a first loan) play a central part in the construction and reinforcement of relationships of trust with clients.

(ii) Local Leadership

Several studies have shown that local leadership can facilitate or slow down the launch of microcredit. In north India, local business networks were very useful for launching a British development project with a microfinance component (Mosse, 2005). Muslim clients in certain villages of Andhra Pradesh in India failed to repay or dropped out of schemes, in partial response to the instructions of local Muslim leaders. Beyond religious factors, these Muslim groups may have been reacting to the end of local employers' monopoly on credit (Joseph, 2013). The fluctuating regional success in the 1990s of a newly launched Crédit Mutuel microcredit program for women in Senegal was partially attributed to how the project was driven forward using "key" people (rural civil servants, elected leaders, local political leaders, men or women), by way of their availability, proximity, or charisma (Guérin, 1999).

These examples indicate that in some villages, local leaders play an active role in influencing the image of microcredit, whether negatively or positively. We encountered cases of local leaders who borrowed and defaulted publicly and called on their whole village to do the same (branch LJ). We also met local politicians who publicly urged villagers to default. Promises of protection for defaulters are part of their political campaign (villages around Brachoua in LJ branch). This may explain very high participation rates in areas where there is low economic demand. In contrast, some credit officers state that they 
approach local leaders with the "moral authority" to intervene and incite poor payers to repay (AW branch).

Both credit officers and local leaders have therefore been key actors in facilitating, slowing down or disrupting the establishment of the microcredit scheme studied here, notably in terms of framing its legitimacy and its ethics. Their role helps to explain disparities between villages in areas with the same agro-ecologic and economic patterns. As Shipton argues, "the ethics of repayment and default are very much bound up with the social distances perceived between borrowers and lenders" (Shipton, 2010: 226). Credit officers, and at times local leaders, partly frame repayment and default ethics, which strongly influences whether people are willing to take on credit or not.

(d) Which factor prevails?

Our analysis sheds light on three main factors in explaining both participation and default behaviours to the microcredit program offered by Al Amana: agro-ecological conditions, social norms related to debt, including how villagers perceive Al Alamana and finally the embeddedness of microcredit in local social networks (see also Bähre, 2007 and Peebles, 2010). Then one may wonder how these factors work together, intermingle or on the contrary come into conflict. Only a long-term ethnographic analysis could allow us to examine in detail the interactions between different factors. However we can still identify broad trends. Eco-type distinctions are not only a matter of production processes, technical constraints and crop type. They are also constitutive of identities, social norms and relations to authority.

For instance, it is likely that the more families are vulnerable, the more they are risk-averse. Fear and self-exclusion are probably most prevalent among the most economically and socially vulnerable families, and as a way of consequence they are probably more prevalent in mountainous regions. In addition, mountainous regions have mainly Berber population. Yet it is well-known that Berber communities, especially in the South, have always been somewhat alienated from the Maghzen. In the end, it seems that in mountainous regions, economical and social factors against microcredit tend to reinforce each other. Credit officers and local leadership can temporarily compensate for the reluctance for microcredit, but the latter prevails in the long run. Conversely, extensive farming areas combine both 
higher wealth (given that remittances also contribute significantly to household income) and a relative feeling of impunity toward the central authority. Credit policy history and prior experiences debt cancellation, common in the agricultural sector but mostly in extensive farming areas, have shaped local norms where repayment default is viewed as legitimate. In the Rif region and its surroundings, characterized by cannabis farming and illegal dealing of all kind, high degree of corruption and illegal activities strengthen even further this feeling of impunity. While the microcredit supply hardly fits the demand, households do not hesitate to borrow as they don't fear any sanction in case of non-payment. This is all the more the case when credit officers are considered as outsiders and when local leaders call for non-payment. In peri-urban villages, where the nature of labour markets and consumer needs fit more to the microcredit supply, the role of credit officers and local leaders can be decisive in slowing down the participation and in some cases in increasing it artificially due to calls for non-payment. We can interpret disparities in repayments (table 4 above) at the light of the above arguments. In our sample, portfolio at risk in Tighdouine (mountain area) and My Abdellah Ben Driss (peri-urban area) is negligible $(0.18 \%$ and $0.85 \%$ respectively). By contrast, the portfolio at risk is 22 per cent in Brachoua (extensive farming) and reaches 37.4 per cent in Moulay Yacoub (a combination of peri-urban and extensive farming at the border of the Rif).

\section{CONCLUSION}

Our findings have a number of key implications. From a methodological perspective, they highlight the importance of conducting qualitative studies alongside the randomised approach (now considered as the gold standard to assess impact of poverty reduction policies) in analysing how people make use of microcredit services. Qualitative approaches are helpful to foster understanding of the mechanisms at play in the decision process as to whether to become a microcredit client or not as well as how people appropriate microcredit. Such insight is important prior to launching microcredit schemes (ex-ante) but also, for our purposes, provides a key addition to impact evaluations based on RCT once a microcredit scheme has been established (ex-post). The most important challenge in the J-PAL impact study was 
that the take-up rate was too low to detect small effects when comparing treatment units with controls. The team had to adapt its sampling method and introduce measures to enhance take-up rates -which also raises the question as to why a very different microcredit scheme to a "normal" one was used, and whether RCTs are appropriate for development programs where adherence is poor (Naudet et al., 2012)). But these research protocol changes were not enough: the take-up rate was still found to be lower than expected. J-PAL argued that high credit constraints caused low formal and informal credit service usage. Differences in households' levels of investment opportunities, etc., were also thought to govern demand for microcredit (Crépon et al., 2011). Our qualitative study challenges these interpretations. Our subsample of the J-PAL study villages shows that households have very varied perceptions of credit use and repayment obligations, and that these perceptions are influenced by a wide range of factors, which are not only economic but also social, cultural and political, at both individual and social group levels From a conceptual perspective, our findings indicate that microcredit "markets" do not result from supply confronting demand, but instead, are historical, political and social constructs. Local perceptions of debt are fundamental to this. In general, we found that there was reluctance to get into debt, while inkind savings were a much more common and accepted cash flow management strategy, including for small businesspeople. Understanding perceptions of specific forms of debt and of creditors (in this case the microcredit association Al Amana) are also vitally important. We found that perceptions not just of $\mathrm{Al}$ Amana, but also of authority and power varied widely, and that $\mathrm{Al}$ Amana was frequently linked to the central State. Beyond structural factors such as local histories of relationships with the State, some social actors are also actively help to construct the legitimacy - or lack thereof - of microcredit. In terms of policy, our findings help to explain the challenges financial inclusion interventions face in rural areas. Agro-ecological particularities are a first challenge that rural microcredit interventions still struggle to meet (Morvant-Roux, 2009). Al Amana came later to the rural market probably because it was more expensive and also because they knew it was challenging. Once they decided to target rural areas, they clearly underestimated the challenges, both economically and socially. Neither were they aware of the diversity of local conditions. Our results were shared and discussed with Al Amana's top management. They were well received and followed by several initiatives from Al Amana to adapt its 
offer. With regards to regional diversity, since our research Al Amana has undertaken to reflect on supply diversification. It remains to be seen whether the significant costs - at least in the short term - of such diversification will be compatible with profitability constraints. Relying on credit officers, as we suggested them, could be a cheap option for improving the quality of the supply. Presently they have no voice within the organization, while most have considerable knowledge of local contexts. Familiarity with local practices would not suffice to design appropriate financial services, but workshops for loan officers to share knowledge and experience with the designers of new products could be envisaged. This would also facilitate agents' acceptance of the new products.

In terms of reluctance to borrow, our results support Al Amana's inclination to offer savings services, but laws regulating microfinance in Morocco don't allow this sector to collect savings. Despite lobbying from the main stakeholders of the microcredit industry, the new law still fails to consider that savings collection as part of their mission. Some stakeholders have also turned to Islamic loans compatible with the Sharia, to ensure better repayment performance and reduce the reluctance to borrow, but it is too early to evaluate the performance of such loans.

Our work also highlights that massive repayment defaults in certain areas mainly stem from the lack of legitimacy of microcredit providers who are placed on the same footing as the Marghzen - the central authority - or as foreign aid, meaning that people simply don't want to pay back. This finding challenges a common hypothesis that there is a strong relationship between repayment defaults and borrower overindebtedness. This opens interesting future research questions for untangling the variety of causes of repayment defaults, to better address the delinquency crisis the microfinance sector faces in many countries.

Last but not least, the microcredit industry should also question its raison d'être: not all the rural poor may need microcredit services. The narrative that accompanied the emergence and huge growth of the microfinance industry and gave microfinance one of the highest profile policies for fighting poverty was based on two naive assumptions. The first was that the poor are all potential entrepreneurs, and the second that contractual innovations would allow microcredit offers to inevitably meet unmet demand among the poor. In Morocco, as in many other contexts, microfinance services offered are drawn up 
more in terms of the constraints of the supply (top-down) than in terms of demand. Our study offers fresh evidence that not all the rural poor need microcredit. However in a context of growing financialization of everyday life, including in remote areas of the developing world, the poor do need access to adequate financial services (Servet $\&$ Saiag, 2013). To be effective and legitimate, such supply must be grounded both in people's financial needs and constraints, and in local economies (Shipton, 2010).

\section{REFERENCES}

Aglietta, M. \& Orléans, A. (1998). La monnaie souveraine, Paris : Editions Odile Jacob.

Armandariz, B. Labie, M. (2011). The Handbook of Microfinance, London/Singapore: World Scientific Publishing.

Aubert, C., A. de Janvry et E. Sadoulet (2009). Designing Credit Agent Incentives to Prevent Mission Drift in Pro-poor Microfinance Institutions, Journal of Development Economics, vol. 90, 1, pp.153-162.

Bähre, E. (2007). "Reluctant solidarity: Death, urban poverty and neighbourly assistance in South Africa." Ethnography 8(1): 33-59.

Bloch, M. \& Parry, J. (1989). Money and the Morality of Exchange, Cambridge : University Press, Cambridge.

Boucher, S.R. Guirkinger, C. and Trivelli, C. (2009). Direct Elicitation of Credit Constraints: Conceptual and Practical Issues with an Application to Peruvian Agriculture. Economic Development and Cultural Change 57(4): 609-640 
Bouman, FJA. (1994). Informal rural finance: an Aladdin's lamp of information. In Financial Landscape Reconstructed: The Fine Art of Mapping Development, Bouman, FJA. Hospes, O. (eds). Westview Press: Boulder, CO, Chap. 7: 1-9.

Bouman, FJA, Hospes O (eds). (1994). Financial Landscape Reconstructed: The Fine Art of Mapping Development. Westview Press: Boulder, CO.

Bourdieu, P. (1977). Algérie 60. Structures économiques et structures temporelles, Paris : Les éditions de Minuit.

Cherifi, R. (1988). Le Makhzen politique au Maroc. Hier et aujourd'hui, Casablanca : Afrique-Orient,

Collins, D. Morduch J. Rutherford S. Ruthven O. (2009). Portfolios of the Poor: How the World's Poor Live on $\$ 2$ a Day. Princeton : Princeton University Press.

Crépon, B., Devoto, F., Duflo, E., Pariente, W. (2010). Evaluation de l'impact du microcredit en zone rurale au Maroc. Agence Française de Développement, december 2010.

Crépon, B., Devoto, F., Duflo, E., Pariente, W. (2011). Impact of microcredit in rural areas of Morocco: Evidence from a Randomized Evaluation. Working paper, J-Pal, March 31, 2011. Available at:http://www.povertyactionlab.org/publication/impact-microcredit-rural-areas-morocco-evidence$\underline{\text { randomized-evaluation }}$

Deneulin, S. \& Rakodi, C., (2011). Revisiting religion: development studies thirty years on. World Development, 39 (1), pp. 45-54.

D’Espallier, B. Guérin, I. Mersland, R. (2011). Women and repayment in microfinance. A global analysis. World Development, 39(5): 758-772.

Duflo, E. Crépon, B. Parienté, W. Devoto, F. (2008). Poverty, Access to Credit and the Determinants of Participation in a New Micro-credit Program in Rural Areas of Morocco, Série Analyse d'Impact Ex Post $n^{\circ}$ 2, Paris : Agence Française de Développement, October 2008.

Fernando, J. (2006). Microfinance. Perils and Prospects, Routledge: Londres. 
Goetz, A.-M. (2001). Women Development Workers. Implementing Rural Credit Programmes in Bangladesh, Sage Publications, London.

Gudeman, S. (2001). The Anthropology of Economy: Community, Market, and Culture. Blackwell.

Guérin, I. (1999). Le dilemme proximité viabilité en microfinance : confiance et partenariats. Savings and Development, 23 (2): 58-72.

Guérin, I. (2006). Women and money: multiple, complex and evolving practices. Development and Change, 37(3): 549-570.

Guérin, I. (2011). Do women need specific microfinance services? In Armendariz B. \& Labie M. (eds) Handbook of Microfinance, London/Singapore: World Scientific Publishing, pp. 563-589.

Guérin, I. Morvant-Roux, S, \& Servet, J.-M. (2011). Understanding the diversity and complexity of demand for microfinance services: lessons from informal finance. In Armendariz B. \& Labie M. (eds) Handbook of Microfinance, London/Singapore: World Scientific Publishing, pp. 101-122.

Guérin, I. Roesch, M. Venkatasubramanian, G. D’Espallier B. (2012a). Credit from whom and for what? Diversity of borrowing sources and uses in rural South-India. Journal of International Development, 24: S122-S137.

Guérin, I. Roesch, M. Michiels, S. Venkatasubramanian, G. (2012b). Dettes, protections et solidarités en Inde du Sud. Economie et Sociétés, tome XLVI (2) : 385-413.

Guérin I. D’Espallier B. Venkatasubramanian G. (2012c) Debt in Rural South India: Fragmentation, Social Regulation and Discrimination, Journal of Development Studies, 0(0): 1-17.

Guérin, I. Morvant-Roux, S. \& Villarreal, M. (2013) (eds) Microfinance, debt and over-indebtedness. Juggling with money, London: Routlegde.

Guillen, P. (1970). La résistance du Maroc à l'emprise française au lendemain des accords franco-anglais d'avril 1904. Revue de l'Occident musulman et de la Méditerranée, vol. 8, 1, pp. 115-122.

Guirkinger, C. (2008). Understanding the Coexistence of Formal and Informal Credit Markets in Piura, Peru. World Development, vol. 36, 8, pp. 1436-1452. 
Guyer, J. - ed. - (1995). Money Matters. Instability, Values and Social Payments in the Modern History of West African Communities, London: .James Currey, Heinemann, Portsmouth (N.H.)

Hann, C. \& Hart, K. (2011). Economic anthropology, Cambridge: Polity Press.

Harper, M. (2003). Microfinance - Evolution, Achievements and Challenges, London, ITDG Publishing.

Harriss-White, B. Colatei, D. (2004). Rural credit and the collateral question. In Harriss-White B. Janakarajan S. (eds) Rural India Facing the 21st Century. Essays on long Term Change and Recent Development Policy. London: Anthem South Asian Studies, 252-283.

Johnson, S., N. Mule, R. Hickson and W. Mwangi (2003). The managed ASCA model innovation in Kenya's microfinance industry. In M. Harper (ed) Microfinance: Evolution, Achievements and Challenges, pp. 159-171. London, ITDG Publishing.

Johnson, S. (2004). Gender Norms in Financial Markets: Evidence from Kenya. World Development, vol. 32,8 , pp. $1355-1374$.

Johnson, S. (2005). Fragmentation and Embeddedness: An Alternative Approach to the Analysis of Rural Financial Markets. Oxford Development Studies 33(3-4): 357-375.

Johnson, S. and Nino-Zarazua, M., (2011). Financial access and exclusion in Kenya and Uganda. The Journal of Development Studies, 47 (3), pp. 475-496.

Johnson, S. (2013). Debt, over-indebtedness and wellbeing: an exploration. In Guérin et al. op. cit.

Joseph, N. (2013). Mortgaging Used Saree-skirts, Spear-heading Resistance: Narratives from the Microfinance Repayment Standoff in Ramanagaram, India, 2008-2010. In Guérin, I. Morvant-Roux S. \& Villarreal M. (eds.), Microfinance, debt and over-indebtedness. Juggling with money, London: Routlegde.

Kochar, A. (1997). An empirical investigation of rationing constraints in rural credit markets in India. Journal of Development Economics, 53:339-371. 
Labie, M., Méon, P.-G., Mersland, R., Szafarz, A., (2010). Discrimination by Microcredit Officers: Theory and Evidence on Disability in Uganda. CEB Working Paper n ${ }^{\circ} 10 / 007$.

Lamrini, R. (2008). Les chevaliers de l'infortune. Microcrédit au Maroc : la Génèse, Rabat : Editions Marsam, $184 \mathrm{p}$.

Long, N. (2001). Development Sociology. Actor Perspectives. London: Routledge.

Long, N. \& Long A. (1992). Battlefields of knowledge:The Interlocking of Theory and Practice in Social Research and Development. London: Routledge.

Lont, H. et O. Hospes - ed. - (2004). Livelihood and Microfinance. Anthropological and Sociological Perspectives on Savings and Debt, Eburon Academic Publishers, Delft.

Malamoud, C. (ed.) (1988). La dette. Paris : Éditions de l'École des hautes études en sciences sociales (coll. Purushartha, vol. 4)

Mersland, R. D'Espallier, B. \& Supphellen, M. (Forthcoming). The effect of religion on development efforts: Evidence from the microfinance industry and a research agenda. World Development.

Morvant-Roux, S. (2006). Processus d'appropriation des dispositifs de microfinance : un exemple en milieu rural mexicain, Thèse de doctorat en sciences économiques, Université Lumière, Lyon 2, Lyon. Morvant-Roux, S. (ed.) (2009). Quelle microfinance pour l'agriculture des pays en développement ? In Exclusion et liens financiers, Paris : Economica, 458 pp.

Morvant-Roux, S. Bouquet, E. \& Rodriguez-Solis, G. (2012). Labor arrangements and financial inclusion of agricultural workers in a dynamic agricultural region in Mexico: exploring the linkages. RUME- Working paper $N^{\circ} 19$ (http://www.rume-rural-microfinance.org/spip.php?rubrique2- Last access 11/27/2012).

Mosse, D. (2005). Cultivating Development. An Ethnography of Aid Policy and Practice, Pluto Press, London. 
Naudet, J.-N., Bernard, T. Delarue, J. (2012) «Évaluations d'impact : un outil de redevabilité ? Les leçons tirées de l'expérience de l'AFD », Revue d'économie du développement 4 (26) : 27 48.

Peebles, G. (2010). "The Anthropology of Credit and Debt." Annual Review of Anthropology 39: 225240.

PlaNet Finance (2006). Étude sur les endettements croisés. Maroc, PlaNet Finance.

Rankin, K. N. (2002). Social capital, microfinance and the politics of development. Feminist Economics, $8(1): 1-24$.

Reed, L. R. (2011). Etat de la campagne du sommet du microcrédit. Rapport 2011, Washington : Microcredit Summit Campaign.

Servet, J.-M. (ed) (1995). Épargne et liens sociaux. Études comparées d'informalités financières, Paris: AEF/AUPELF-UREF.

Servet, J.-M. (2006) Banquiers aux pieds nus. La microfinance. Paris : Odile Jacob.

Servet, J-M. \& Saiag, H. (2013). Household over -indebtedness in northern and southern countries: a macro-perspective. In Guérin, I. Morvant-Roux S. \& Villarreal M. (eds.), Microfinance, debt and overindebtedness. Juggling with money, London: Routlegde.

Shipton, P. (2007). The Nature of Entrustment. Intimacy, Exchange and the Sacred in Africa, Yale University Press, New Haven, London.

Shipton, P. (2009). Mortgaging the Ancestors: Ideologies of attachment in Africa, New Haven, CT and London: Yale University Press, 2009. 336 pp.

Shipton, P. (2010). Credit between cultures. Farmers, financiers and misunderstandings in Africa, NewHaven \& London: Yale University Press. 
Silva-Gonçalves, J. (2011). Les contraintes de crédit en milieu rural marocain. mémoire de Master, Université paris 1-PSE, pp. 62.

Stiglitz, Joseph E., and Andrew Weiss (1981). Credit Rationing in Markets with Imperfect Information. American Economic Review 71, 393-410

Thérêt, B. (2009). Monnaie et dettes de vie. L'Homme, 190 : 153-179.

Tripp, C. (2006). Islam and the moral economy: The challenge of capitalism. Cambridge: Cambridge University Press.

Tsai, S. K. (2004). Imperfect substitutes: the local political economy of informal finance and microfinance in rural China and India. World Development 32(9), pp. 1487-1507.

Villarreal, M. (2009). Social Boundaries and Economic Dilemmas in Micro-financial Practices. First European Research Conference on Microfinance, CERMi, ULB, June 2-4, Bruxelles.

Villarreal, M. (2004). Striving to Make Capital do 'Economic Things' for the Impoverished: On the Issue of Capitalization in Rural Microenterprises. In Kontinen, T. (ed), Development Intervention. Actor and Activity Perspectives, University of Helsinki, Helsinki, pp. 67-81.

Zelizer, V. A. (1995). The Social Meaning of Money. New York: Basic Books.

Zombre, U. (2013). "Marchés du crédit et marchés de la terre à Madagascar: interfaces et implications pour le développement agricole". Thèse de Doctorat en Sciences Économiques, Montpellier SupAgro, Montpellier (France).

Table 1. Take-up rate variation across regions

\begin{tabular}{|l|c|}
\hline $\begin{array}{c}\text { Take-up rates (wave 2, } \\
\text { 37 branches, dec-09) }\end{array}$ & $\begin{array}{c}\text { \% of branches } \\
\text { (regions) }\end{array}$ \\
\hline 0 to $9 \%$ & $47 \%$ \\
\hline 10 to $19 \%$ & $19 \%$ \\
\hline 20 to $29 \%$ & $19 \%$ \\
\hline Over $30 \%$ & $16 \%$ \\
\hline
\end{tabular}


Source: Al Amana and J-Pal follow up of take-up rates

Table 2. Interviews detailed sample

\begin{tabular}{|l|c|}
\hline Clients & $\mathbf{3 6}$ \\
\hline Non-clients & 23 \\
\hline Imams & 6 \\
\hline Shop keepers & 9 \\
\hline Credit officers & 5 \\
\hline Total & 79 \\
\hline
\end{tabular}

Table 3 Branches included in the sample and take-up rates

\begin{tabular}{|l|c|c|}
\hline Branch Name & $\begin{array}{l}\text { Take-up rate } \\
\text { (dec. 2009) }\end{array}$ & $\begin{array}{l}\text { Min-Max take-up rates for treatment } \\
\text { villages of the branch (dec. 2009) }\end{array}$ \\
\hline CV Tighdouine & $6 \%$ & $0-7 \%$ \\
\hline MG My Abdellah Ben Driss & $20.8 \%$ & $5 \%-43 \%$ \\
\hline AW Moulay Yacoub & $19.6 \%$ & Only one observation reported \\
\hline LJ Brachoua & $1 \%$ & Only one observation reported \\
\hline
\end{tabular}

Source: Al Amana and J-Pal follow up of take-up rates 
Table 4 Typology of visited branches according to eco-type systems

\begin{tabular}{|l|l|l|l|}
\hline Branch & Eco type system & $\begin{array}{l}\text { Take-up (dec. } \\
\text { 2009) }\end{array}$ & $\begin{array}{l}\text { Portfolio at risk (30 } \\
\text { days) 2010 }\end{array}$ \\
\hline CV Tighdouine & Type 1 : Mountain area & $6 \%$ & $0.18 \%$ \\
\hline MG My Abdellah & Type 2 : Peri-urban area & $20.8 \%$ & $0.85 \%$ \\
\hline AW Moulay & Type 2 et 3 : Peri-urban and & $19.6 \%$ & $37.4 \%$ \\
\hline Yacoub & extensive farming area & & $22 \%$ \\
\hline LJ Brachoua & Type 3 : Extensive farming area & $1 \%$ & \\
\hline
\end{tabular}

Source: Al Amana and J-Pal follow up of take-up rates and and Al Amana's reporting of repayment defaults

\footnotetext{
${ }^{\mathrm{i}}$ Morocco has a total population of 31,285,174.

ii JPAL divided the regions where Al Amana wanted to introduce its services into four zones (called waves) where credit services developed progressively: Wave 1, then Wave 2, etc. JPAL's investigations followed this progressive set up. To prevent hindering the development of the impact study, our study focused on the areas and branches covered by Wave 2 of the JPAL investigation. Wave 2 comprises 37 branches mostly opened in 2008.

iii Jpal and Al Amana recorded take-up rates for each branch and village between 2007 and 2009

iv See case studies in rural Mexico (Morvant 2009; Villarreal 2009), rural India (Guérin et al. 2009) and rural Kenya (Johnson 2004; Shipton 2007).

${ }^{\mathrm{v}}$ This was analyzed, notably, by the sociologist Pierre Bourdieu during mountain village investigations in Kabylie in Algeria (but also in the gatherings and slums around Alger) in the 1950s (Bourdieu, 1977).

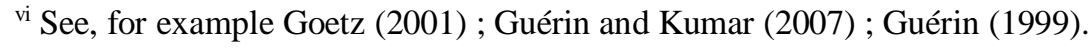


${ }^{\text {vii }}$ We believed that targeting clients could have been facilitated by family or tribal links between agents and clients. However, this does not seem to be the case.

viii Whereas active discrimination implies that credit officers or members of credit committees systematically reject credit demands from some categories of the population based on ethnical, religious, or physical criteria, passive discrimination arises when credit officers spend less efforts to reach specific categories of the targeted population. 